\title{
The French Connection, or Pórr versus the Golem
}

\author{
Richard Cole \\ Department of Germanic Languages \& Literatures, Harvard University, \\ 365 Barker Center, 12 Quincy Street, Cambridge, MA 02138, USA \\ e-mail: richardcole@fas.harvard.edu
}

\begin{abstract}
This article investigates the extent to which Jewish exegetical and magical traditions were known in medieval Scandinavia. Particular attention is paid to the mythological work, Snorra Edda (ca. 1220), and the prose narrative Porleifs páttrjarlsskálds (ca. 1300). In Snorra Edda, we encounter the character of Mokkurkálfi, a clay giant who has been magically animated to defend the race of giants against the god Thor (Pórr). In Porleifs páttr jarlsskálds, a similarly animated "trémaðr" ("wooden man") is sent on an assassination mission to dispatch a troublesome poet. Both these figures are considered in light of various traditions pertaining to the golem. Possible routes of transmission between the Jewish and Scandinavian worlds are considered to explain these similarities, with a special focus on Norwegian students at the Abbey of St. Victor.
\end{abstract}

\section{Keywords}

Old Norse - Scandinavia - runes - Snorra Edda - golem - Jewish magic - Sefer Toledot Yešu - St. Victor 


\section{Introduction}

The stone giants made her want to write. They filled the world with alarming energy and power.

A.s. BYATT, Ragnarök. The End of the Gods ${ }^{1}$

At a farmstead in Western Iceland, in the year 1220 or thereabouts, the chieftain and author Snorri Sturluson is composing a retelling of the mythical fight between the god Pórr and the giant Hrungnir. He has a wide range of sources to draw upon: ancient poetry from the age of paganism, rhetoric from his student days at Oddi, the tomes of European learning that regularly make their way across the Atlantic to his homeland, and the discussions he has had with learned men on his visits abroad to Norway and Sweden. The story, as Snorri tells it, begins with a brooding standoff. Pórr has come to exact vengeance on Hrungnir, who has become a threat to the gods. On the one side stand Pórr and his protégé, Pjálfi. On the other stands Hrungnir. He too has brought a companion. This strange creature is named Mǫkurkálfi ("Mud-leg”), a magically animated giant, sculpted from clay. He has been created to serve as a defender to the giants but is poorly suited to the task. He is racked by fear, only just born to the world and yet soon to depart it. Pórr charges for Hrungnir, wielding his mighty hammer, Mjollnir. pjálfi takes on the mud man. For a moment, Mekkurkálfi catches sight of Pórr on the warpath. He loses control of his bladder. Moments later, he is dead at Pjálfi's feet. As shall be seen, Hrungnir was not Snorri's own invention, but Mekkurkálfi appears only in Snorri's Edda. The clay giant instantly recalls the Jewish golem. But how likely might it be that any Jewish traditions should have reached Iceland, a place where the nearest Jew would have been more than a thousand miles away, in England?

While Snorri never lived in a land that had a Jewish population, he did live in a time where violence against Jews was commonplace, and contemplation of their position as "Other" was a staple of European intellectual life. ${ }^{2}$ By the time of Snorri's death in 1241, the Jews of London, York, Oxford, Bury St. Edmonds and Fulda had all been implicated in blood libels, Crusaders had massacred more than 2500 Jews in northern France, and Pope Gregory IX had put the Talmud on trial in Paris. But lest we should err into conceiving of

1 A.S. Byatt, Ragnarök. The End of the Gods (Toronto, on: Alfred A. Knopf, 2011), 10.

2 The initial description of medieval Europe as a "persecuting society" was provided by R.I. Moore. He pays particular attention to the twelfth and thirteenth centuries in the second edition of his book: Robert Ian Moore, The Formation of a Persecuting Society. Authority and Deviance in Western Europe 950-1250 (New York, NY: Wiley-Blackwell, 2006), 144-171. 
Jewish-Christian relations during Snorri's lifetime relations entirely as a historia lacrimosa, it is also important to remember that the tendency towards anti-Judaism and anti-Semitism was never the universally accepted position. Indeed, while Crusaders battled Muslims in the East and mobs attacked Jewish communities at home, European intellectuals unapologetically devoured Islamic and Jewish learning. Many Christians were comfortable with the Jewish roots of their own faith, and sought out Jews who could elucidate exegetical points in the Old Testament. Some medieval Christians studied the Hebrew language. St. Jerome and St. Isidore are well known examples, but Hebraism in the Middle Ages was by no means limited to the Mediterranean. Pádraic Moran has highlighted how Irish clergymen had been "reverse engineering" an understanding of the Hebrew language from as early as the seventh century. ${ }^{3}$ Snorri's age, namely the thirteenth century, saw the flourishing of Hebraism in England too. There, the monks of Ramsey Abbey were obtaining and studying Jewish manuscripts. William de Arundel (d. 1239) was even composing polemics in Hebrew. Although there is a debate over the extent of the great Robert Grosseteste's (d. 1253), Hebrew knowledge, it is certain that he had at least some grasp of the language. ${ }^{4}$

While Christian Hebraism budded in the British Isles, it truly flourished in France. One of the key locations of Jewish-Christian intellectual exchange was the abbey of St. Victor, just outside of Paris. The study of Hebrew had already begun there in the twelfth century with Hugh of St. Victor (fl. 1120s), who was the first master known to have some comprehension of the language. ${ }^{5}$ The growing population of French Jews would have provided ample opportunities for inter-religious learning, although the rabbis probably served more as "consultants" than permanent teachers at the abbey—the students may well have

3 Pádraic Moran, "Hebrew in Early Irish Glossaries," Cambrian Medieval Celtic Studies 60 (Winter, 2010), passim.

4 On Ramsey Abbey, see Lucy Freeman Sandler, "Christian Hebraism and the Ramsey Abbey Psalter," Journal of the Warburg and Courtauld Institutes 35 (1972). See also: Joseph Mihelic, "The Study of Hebrew in England," Journal of Bible and Religion 14, no. 2 (1946), 96. On the much-neglected case of William de Arundel, see Cecil Roth, A History of the Jews in England (Oxford: The Clarendon Press, 1964), 129-131. On Robert Grosseteste's putative Hebraism, see S. Harrison Thomson, The Writings of Robert Grosseteste. Bishop of Lincoln 1235-1253 (Cambridge: Cambridge University Press, 1940), 38-39. For a recent proposal that Grosseteste fully understood Hebrew, see James McEvoy, Robert Grosseteste (Oxford: Oxford University Press, 2000), 120-121.

5 Beryl Smalley, The Study of the Bible in the Middle Ages, (Notre Dame: University of Notre Dame Press, 1978), 103. For Smalley's thorough overview of the Victorines and the Hebraists amongst them more generally, see $83^{-195}$.

MEDIEVAL ENCOUNTERS 20 (2014) 238-260 
learnt their Hebrew from fellow Christians. ${ }^{6}$ Particularly important amongst the Jews contributing to the intellectual milieu at St. Victor were direct successors of the renowned Rashi of Troyes (d. 1104). Rashi (Rabbi Shlomoh Yiṣhaqi) was born into a rabbinic family, and studied at yeshivot in Worms and Mainz before establishing his own academy in Troyes. He would have lived through the anti-Jewish violence of the First Crusade in $1096 .^{7}$ It is difficult to overstate the importance of Rashi's position within Judaism. He wrote extensive commentaries on the Tanakh and the Talmud, drawing on an intimate knowledge of complex legal issues, opaque points of grammar, and the long tradition of commentary that preceded him. Rashi's work forms the basis of Talmudic criticism even today. For scholars who are mainly familiar with medieval Christendom, it may be helpful to liken Rashi's role within Judaism to that of St Augustine within Christianity.

We will return to Rashi and the Victorines later, but for now it will suffice to underline the illustrative irony here; that a man who in his own lifetime witnessed rhetorical and physical attacks on his faith, also had an arterial entry into the premier institution of learning in Christendom after his death. This dichotomy exemplifies the two opposed, but not exclusive, tendencies to which we have alluded earlier: (1) the impulse to denounce and denigrate Jews; (2) the utility of knowledge inherited or acquired from Judaism. The general aim of this paper, then, is to illustrate the extent to which the Christian learned tradition transmitted knowledge ultimately derived from Judaism into medieval Scandinavia. In particular, I am interested in how certain Jewish exegetical and magical practices may have exerted an influence on Snorra Edda. ${ }^{8}$ As shall be seen, any such influences would have been coloured by the two aforementioned attitudes towards Jews exhibited by medieval Christian intellectuals.

6 On contacts between Jews and Victorines, see Rainer Berndt, "The School of St. Victor in Paris," in Hebrew Bible/Old Testament: the History of its Interpretation, vol. 1, part 2, ed. Magnus Sæbø (Göttingen: Vandenhoeck \& Ruprecht, 200o), especially at 487-492. On the degree of self-sufficiency amongst Hebraists, see Aryeh Grabois, "The Hebraica Veritas and JewishChristian Intellectual Relations in the Twelfth Century," Speculum 50, no. 4 (1975), 620-623.

7 For recent comment on the debate over whether Rashi's writing alludes to this unrest, see Devorah Schoenfeld, Isaac on Jewish and Christian Altars: Polemic and Exegesis in Rashi and the Glossa Ordinaria (New York, NY: Fordham University Press, 2013), 18-19.

8 Consideration of Snorri as a Christian intellectual is not a novel proposal. See, for example Bjarne Fidjestøl, "Snorri Sturluson-European Humanist and Rhetorician," in Selected Papers, ed. Odd Einar Haugen and Else Mundal, trans. Peter Foote (Odense: Odense University Press, 1997), 343-350; Anthony Faulkes, "The Sources of Skáldskaparmál: Snorri's Intellectual Background," in Snorri Sturluson: Kolloquium anlasslich der 750. Wiederkehr seines Todestages, ed. Alois Wolf (Tübingen: Narr, 1993), 59-76. 
We will begin by sketching out the amount of Jewish learning that had reached Scandinavia by the time Snorri was writing.

\section{Attitudes towards the Hebrew Language and Jewish Magic}

The most visible Jewish import in medieval Scandinavia is arguably the use of Hebrew in magical runic inscriptions. Space does not allow for discussion of the faux Hebrew etymologies in The First Grammatical Treatise (ca. 1150) and The Third Grammatical Treatise (ca.1250), or the Hebrew alphabet preserved in Arnamagnæan Collection manuscript AM 685d 4to (ca. 1450-1499), although scholars have generally been wary of attributing any real knowledge of Hebrew to these sources (the question of Hebraism in Scandinavia is a complex one, which warrants a separate study). ${ }^{9}$ There are seven inscriptions that address God with Hebrew epithets, and a further twenty-eight that deploy the originally Jewish "agla" [אגלא] acronym as a magical formula. The Hebrew found in runes is generally formulaic, limited to occurrences also known in the standard Christian liturgy, and is thus not indicative of Hebraism in the true sense of the word. That said, rare inscriptions such as $\mathrm{N}_{348}$, a wooden amulet from Norway carved during the High Middle Ages, suggest a more nuanced understanding of the language, if not on the part of the carver than at least on the part of their informant:

§A emanuel sabao ad.'onai usion agios opannapos ælæison alfa æp o

$\S \mathrm{B}$ messias soper

§C filæhs artifæhas deus iesus saluator agios oponnapos ælæison aæl (g)aagelai ag $(\mathrm{e}=) \mathrm{la}^{10}$

עמנואל צבאות אדני וציון 'A 'A

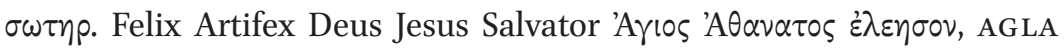
[אגלא]

See: Anne Holtsmark, En Islandsk Scholasticus fra det 12. Århundrede (Oslo: Jacob Dybwad, 1936), 72-75; Ian McDougall, "Foreigners and Foreign Languages in Medieval Iceland," Saga-Book 22 (1986-1989), 198; Einar Haugen. Notes to First Grammatical Treatise. The Earliest Germanic Philology ed. Einar Haugen (London: Longman, 1972), 74; Hreinn Benediktsson. Notes to The First Grammatical Treatise ed. Hreinn Benediktsson (Reykjavík: Institute of Nordic Linguistics, 1972), 194.

10 Transcription taken from Rundata 2.5. Available online at: http://www.nordiska.uu.se/ forskn/samnord.htm. 
God is with us, the Lord of Hosts and Zion. Holy One, Immortal One, have mercy. Alpha and Omega. Messiah, Saviour. Blessed Creator, Lord Jesus the Saviour. Holy One, Immortal One. Have mercy. AG LA.

On its own, an invocation like "צבאות אדני"- - "Lord of Hosts"—is fairly unremarkable. However, the addition of usion, apparently a rendering of "וציוון "and Zion" — can be interpreted as an attempt to innovate a little on the usual Tetragrammaton. We might view this as a humble attempt to produce an original phrase in Hebrew. Mindy MacLeod and Bernard Mees, following Magnus Olsen, prefer to view this element as an erroneous contraction of the word opoov against this reading: firstly, the carver has otherwise demonstrated a good knowledge of formulae. He reproduces complex foreign sounds in a surprisingly consistent and intelligible manner. Secondly, for usion to denote ópoov would disturb the symmetry of his inscription. 'A discrete excerpt from the Tersanctus. To append an isolated ipoovøiov would seem like an uncharacteristically clumsy pretense. Rather than reading this as embarrassing Greek, we can read it as impressive Hebrew. It exhibits an understanding of the Vav-conjunctive and an element of grammar known as the "construct chain" that denotes genitives. The proper form ought to be pronounced ve-șion, but using a $<\mathrm{u}>$ to denote $<\mathrm{l}>$ is both an acceptable transliteration from Hebrew to Runic and an easy mistake for a novice (The vav is pronounced as /u:/ or /ve/ depending on the following word). Whether the carver of $\mathrm{N} 348$ could really read Hebrew is very much in doubt, but he knew a little vocabulary and had a limited familiarity with some of the mechanics of the language. We might call such a level of competency "technical Hebraism"; a smattering of Hebrew was acquired only to be deployed in certain circumstances, in this case for the inscription for a protective amulet. ${ }^{12}$ It is marginally more rarefied than the dumb parroting of phrases lifted from the liturgy, but still a long way from the proper ability to read original texts in Hebrew that could be attained at institutions such as St. Victor.

11 Mindy MacLeod and Bernard Mees, Runic Amulets and Magic Objects (Woodbridge: The Boydell Press, 2006), 193; Magnus Olsen, Norges Innskrifter med de Yngre Runer vol. 4 (Oslo: A/S Bokcentralen, 1954), 140.

12 I suggest this term following work by Michael Signer, who has proposed two other varieties of Hebraism, "lexical Hebraism," where a thorough knowledge of Hebrew on the part of Christians is sought as an end in itself, and "cultural Hebraism" which seeks to engage with contemporary Jewish culture. See: Michael A. Signer, "Polemics and Exegesis: The Varieties of Twelfth Century Christian Hebraism," in: Hebraica Veritas? Christian Hebraists and the Study of Judaism in Early Modern Europe, ed. Allison Coudert (Oxford: University of Pennsylvania Press, 2004), especially at 21-26. 
Dror Segev, the only scholar to pay this topic much attention, is highly skeptical of the prospect that Norse-speaking magicians were aware of any Hebrew origins in their magical formulae. He states that "the Heb[rew] in our runic corpus cannot be seen as used consciously, for the $\mathrm{Heb}[\mathrm{rew}]$ that was used was seen, with much justification, as just another form of Church Latin.,"13 This view is also held by Michael Barnes, who treats the subject in passing. ${ }^{14}$ Doubtless, some magicians were ignorant of the origins of the traditions they utilised. It is unthinkable that every AGLA inscription was inspired by the knowledge that it is an acronym for אתה גבור לעולם אדני. But there are many reasons to suspect that at least in certain circles, Scandinavians did recognise and value "Jewishness." Firstly, Segev's assumption that Latin and Hebrew would have been indistinguishable to rune carvers does not take into account the fact that "runacy" in the Middle Ages was not a pursuit limited to the laity. Rather, many clerics and learned people were responsible for runic inscriptions-indeed, often magical ones. ${ }^{15}$ These are people who would have a solid command of Latin, and therefore be quite capable of telling it apart from Hebrew. The carver of $\mathrm{N} 348$, for example, would appear to have been conscious that he was using three different languages, even if his proficiency therein was extremely limited, and he was relying on common formulae.

Secondly, the common European association of Jews with magic, and of Jewish magic as being especially potent, was certainly known in Scandinavia. ${ }^{16}$ The Messuskýringar demonstrate the common Christian reverence for the Hebrew language which made it such an attractive prospect for use in magic: Alleluia er sungit er á ina ceðztu tungu er ebreska er ("Alleluia is sung in the highest language, which is Hebrew"). ${ }^{17}$ The Theophilus Legend, where an ambi-

13 Dror Segev, Medieval Magic and Magicians - In Norway and Elsewhere. Based Upon 12th15th Centuries Manuscript and Runic Evidence (Oslo: Senter for Studier i Vikingtid og Nordisk Middelalder, 2001), 134 .

14 "Many of these names [for God] are of course, of Greek or Hebrew origin, but they have become part of 'Church Latin,' just as the Hebrew charm acronym agla or the Greek prayer Kyrie eleison, Christe eleison.” Michael Barnes, Runes: A Handbook (Woodbridge: Boydell Press, 2012), 123; see also 112.

15 For some discussion of the methodological problem of discerning clerical/learned from popular in a Scandinavian context, see Stephen Mitchell, Witchcraft and Magic in the Nordic Middle Ages (Philadelphia, PA: University of Pennsylvania Press, 2011), 3-19.

16 A general overview of this prejudice is given by Joshua Trachtenberg, The Devil and the Jews. The Medieval Conception of The Jew and its Relation to Modern Antisemitism (New York, NY: Harper Torchbooks, 1966), 57-96.

17 Messuskýringar. Liturgisk Symbolik frå Den Norsk-Islandske Kyrkja i Millomalderen, vol. 1, ed. Oluf Kolsrud (Oslo: Jacob Dybwad, 1952), 45-46 (my standardisation). 
tious priest makes a Satanic pact through a Jewish sorcerer, is preserved twice in Old Norse. There, the demoniac intermediary is described variously as: einn ebreskr madr miok fiỏlkunnigr, sa sem marga menn hafdi adr suikit dreckiandi pa i grỏf eilifrar tapanar med sinum gỏlldrum ("A very magically skilled Hebrew, who had drowned many men before in the grave of eternal perdition with his witchcraft" $)^{18}$ and ebreus... fullr af eitri illzkunnar sua sem hinn uesti uillumadr ("a Hebrew, full of the poison of wickedness like the most wretched heretic"). ${ }^{19}$ Marian miracle stories such as these, although often preserved in thirteenth or fourteenth century manuscripts, had been circulating in Iceland since at least the days of Jón Qgmundarson, who was bishop of Hólar from 1106-1121 (his saga even depicts him reading a particularly anti-Jewish example of the genre). ${ }^{20}$ Furthermore, if we take The Old Icelandic Homily Book as the earliest work in the canon, then the perception of "the Jew" as somehow occult was present at the very inception of Old Norse literature. One of the sermons on St. Stephen and Gamaliel includes a potted version of St. Augustine's miracle of Petronia (predating its incorporation into Jacobus de Voragine's The Golden Legend $){ }^{21}$ Here, St. Stephen intercedes to heal a sick woman, who in her desperation has turned to a Jewish sorcerer:

Húsfreýia necqver gæofog vas vanheíl. svát lǽcnar mótto eige heNe bót vina. En gypingr necqver talpe pat fyr heNe. at hon bysde í harprǽpe sinom fingr goll pat es steín sa í fólgen. es funden hafpe veret í ocsa nýra. oc magnapr sípan mep forneskio. En hon gerpe sem Gypingr mælte. oc fór pó at sǿkia helgan dóm stefans. En es hon fór leípar sínar hia necqvere. pa sa hon fyrer fótom sér liggia a gato fingr gollet es hon hafpe knýr i hárpræpenom. pa undrapesc hon. oc leítape til harprapar ens. oc fan hon heílan mep æollom rę́xnom sinom. pa grunape hon at fingrgollet mønde brotet vera. oc sloppet af hárprænenom. en eR pat vas osakat. pa hafpe hon iarteín pessa. fyr vitne heílso sinar peiRar es hon vátte af stephano. oc castape hon fingrgolleno a ána. oc tóc hon heílso sem hon

18 "Af Teophilio fogr iartein," in Mariu Saga. Legender om Jomfru Maria og hendes jertegn, efter gamle haandskrifter, ed. C.R. Unger (Christiania: Brögger \& Christie, 1871), 1092-1094.

19 "De Theophilio," in Mariu saga. 409.

20 See Jóns Saga Hólabyskups ens Helga, ed. Peter Foote (Copenhagen: C.A. Reitzels Forlag, 2003), 26-27, 93-94, 129-130.

$21 \quad$ First identified by Johan Fritzner, Ordbog over Det Gamle Norske Sprog. Nytt uforandret opptrykk av 2 utgave (1833-1896), vol. 1 (Oslo: Tryggve Juul Møller Forlag, 1954), 739. For the source, see St. Augustine of Hippo. The City of God, Books XVII-XXII, trans. Gerald G. Walsh \& Daniel J. Honan (Washington, DC: Catholic University of America Press, 2007), 446 . 
vǽtte af enom helga stephano. hafpe sipan gæofogt giaforp i borg peire es cartágo heiter $\because^{22}$

[A certain noblewoman was sick, to the extent that doctors could not treat her. But a certain Jew told her that she should tie to her hairband a ring, in which was concealed a stone which had been found in the kidney of an ox, and then enchanted with magic. And she did as the Jew said, and then went to visit the Cathedral of St. Stephen. But as she went on her way, she saw before her lying in the street the ring which she had attached to her hairband. Then she was amazed, and examined the hairband, and she discovered that it was in one piece, complete with all its knots, then she suspected that the ring must have broken and slipped off the hairband. But as it was intact, she attributed this miracle as proof that her recovery was given to her by St. Stephen, and she threw the ring into the river, and accepted the healing which she received from the Holy Stephen, and then made an excellent marriage match in that city which is called Carthage.]

The Jew's magical abilities here coalesce with several Christian presuppositions surrounding Jews and the supernatural in the Middle Ages. Firstly, there is the troubling gender dynamic:Júðakona seems to be the preferred Old Norse term for female Jewish characters, but it is not the word used here. Rather, the homilist prefers the masculine gyðingr. Thus, the premise of the tale is that a Jewish man is attempting to bewitch a gentile woman. ${ }^{23}$ Although the homilist never makes the purpose of the Jew's ring explicit, the general setting resonates with the trope that the Jewish male desires to seduce or otherwise sexually corrupt the Christian female. However, he is so physically decrepit that he can only do so by resorting to dark arts known exclusively to the Jews. ${ }^{24}$ Secondly, there is the typological juxtaposition of the material against the spiritual. A common motif in medieval anti-Judaism was to align the Jews with unthink-

22 Homiliu-Bók. Isländska Homilier efter en Handskrift från Tolfte Århundradet, ed. Theodor Wisén (Lund: C.W.K. Gleerups Förlag, 1872), 206-207.

23 "Vor frv hialpadi iudakonu," in Mariu saga, 980-981. See also "Fra krepptum mann,er feck heilsv," in Mariu saga, 967. I have found no example of the masculine nouns gyðingr or júði being used to describe explicitly female characters.

24 See, for example, a bizarre French tale where a Jewish woman has her womb removed by a Jewish sorcerer/surgeon, in Miri Rubin, "The Person in the Form: Medieval Challenges to Bodily 'Order,' " in Framing Medieval Bodies, ed. Sarah Kay and Miri Rubin (Manchester: Manchester University Press, 1996), 108. 
ing literalism and gross corporeality. Jewish power, such as it was imagined by Christians, lay in the material world. The Jew's realm was that of unreasoned dogma, matter, and (disgusting) bodies. Christianity, on the other hand, was aligned with ineffability and transcendence. Its power resided in the soul and the unseen. As Steven Kruger writes:

The idea of Jewish and queer bodily degeneracy and danger is linked also to a claim about ideas, a belief that... Jews were not just physically but intellectually perverted, and in particular unable to read and interpret texts properly. Jews, of course, were thought willfully to misunderstand the truth of Christ's life, and of Scripture both "Old" and "New": just as they possess debased bodies, their readings debase texts by focusing only on the material, never the spiritual. ${ }^{25}$

This theme is perfectly exemplified by the homilist's tale. The miraculous means of St. Stephen are unknowable: matter has passed through matter without breaking, and how it was done can never be comprehended by the mortal mind. Thus, the purity of Christian supernatural power is highlighted by its absolute withdrawal from the material world. The contrast with the crude magic of the Jewish sorcerer is so extreme that it verges on bathos. St. Stephen can offer a fantastic circumvention of the normal laws of existence. The Jew can offer the rather unappealing prospect of an ox's kidney stones. Of course, while Jewish magic might be denigrated as filthy, it is still considered sufficiently potent that saintly intervention is required in order to counter it.

One might be tempted to dismiss these episodes as accidental foreign imports, translated into the vernacular but never internalised by native audiences. Bjarne Berulfsen, for instance, described anti-Jewish and anti-Semitic miracle tales as an importvare. ${ }^{26}$ I would take strong exception to such an approach. It supposes that the modern, scholarly artifices of "native" versus "translated" literature were equally valued by medieval Icelanders; indeed, that they were always able to know the original sources of the texts they read-or had read to them aloud at church. It also implies that the expensive scribal business of composition, copying, and transmission frequently had no audience appreciative of the labour involved. However, even if these methodological criticisms were to be considered insufficient, there is some evidence of the aforementioned views on Jewish magic being incorporated

\footnotetext{
25 Steven F. Kruger, "Racial/Religious and Sexual Queerness in the Middle Ages," Medieval Feminist Forum 16, no. 1 (1993), 34-35.

26 Bjarne Berulfsen, “Antisemittisme som litterær importvare," Edda $5^{8}$ (1958), 123-144.
} 
into the vernacular saga form. This redaction of Dínus saga drambláta probably dates from the $1600{ }^{27}{ }^{27}$ The earlier, fourteenth-century redaction does not contain the reference to Hebrew, but it is not unthinkable that this detail was added during an intermediate version created during the remainder of the medieval period:

... geingur k(ongz) dotter med sijnum meyium aptur j syna hóll og getur ad lyta vid nordurætt aa murnum eitt lytid tabulum edur spialld, pad var skriffad med gullstoffum ä ebresku, sem hun getur petta ad lyta bregdur henne nockud vndarliga vid pessa syn, fijrst fleyer hun hóffudgullenu aff sier par med huorju plagge pui sem a henne var fer til og dansar alnakenn fyrer pessare tabula edur spiallde, petta sama gióra allar hennar meyiar pegar pær lyta petta litla letur dansa pær og nactar... petta tabulum leykur alla eins smä og störa ryka og fatæka tigna ok otigna pa peir pad lijta affklædast peir hlaipande suo j dansenn slykt hender kongenn og drottninguna sem alla adra pegar pau lyta spialldid fleyia pau aff sier sinum tignar klædum og hlaupa suo nakenn j dansenn, ed sama gióra aller beir hóffdingiar frwr og jomfrur sem med peim geingu suo aunguer dansa meir enn pesser. $^{28}$

[... the king's daughter goes with her ladies-in-waiting back to their hall, and can see that on the north-facing wall there is a little tablet or placard. It was inscribed with golden letters in Hebrew. As she sees it, she is rather strangely affected by the sight. First she discards her tiara, and with it the rest of the effects she had on, and dances entirely naked before these tablets or placard. All her ladies-in-waiting do the same when they see this little thing. They disrobe and dance ... that tablet deludes everyone, short and tall, rich and poor, noble and common, so that when they look at they take off their clothes, leaping into the dance. That is what happens to the king and queen, just like all the others. When they look at the mirror they discard their noble clothes and then leap naked into the dance. All their barons, ladies, and maidens do the same, so that none dance more than them.]

The Hebrew-inscribed tablet similarly affects the local bishop, abbots, monks and abbesses. We can observe all the same tropes about Jewish magic that we

27 Jürg Glauser, "Dínus saga drambláta," in Medieval Scandinavia. An Encyclopedia, ed. Phillip Pulsiano and Kirsten Wolf (London: Garland Publishing, 1993), 136-137.

28 Dínus saga drambláta, ed. Jónas Kristjánsson (Reykjavík: Háskóli Íslands, 1960), 114-115. Cf., 37-41. 
saw earlier. There is the desire to corrupt gentile sexuality. Moreover, the tabulum clearly belongs to - and operates within — a very physical sphere. Its effect is upon bodies, its power is materially derived from the golden letters. Above all these finer discourses, there is the general perception that Jewish magic is a strange and particularly fearsome force. To return, then, to the position of Barnes and Segev that Hebrew words in runic inscriptions were considered efficacious purely because they were understood as "Church Latin," it seems as though, to the contrary, an understanding of distinctly Jewish magic had indeed permeated the popular consciousness. This is a trend that should be born in mind when we consider Snorri's work. Would an intellectual as eclectic in his tastes as Snorri have found at least some inspiration in the vivid connotations of Jewishness that were circulating in medieval Scandinavia? It is worth noting that the Codex Wormianus manuscript of Snorra Edda seems to mirror the description of Hebrew as the language closest to God we saw earlier. In the prologue, where a euhemerism is used to explain how people lapsed into paganism, it is written that ceingi uissi skapara sinn. utan peir ceiner menn sem toluðu ebreska tungu ("Nobody knew his Creator, except those men who spoke the Hebrew language"). ${ }^{29}$

\section{Snorri and Jewish Traditions}

The extent to which Snorri might have been influenced by Christian thinking about Jews, and/or Jewish learning, are not novel questions. Sophus Bugge, Gabriel Turville-Petre, and Heather O'Donoghue all pointed out some arresting similarities between Jewish material and certain aspects of Snorri's Baldr tale. ${ }^{30}$ For readers who are not closely acquainted with Old Norse, it may be worth briefly recapitulating its key features. According to Snorri, the god Baldr was the most beloved, most radiant and most beautiful of the gods. After a premonition of his own death, his mother Frigg makes everything in creation swear not to harm her son. The only exception, she says is Sá er mistilteinn kallaðr. Sá pótti mér ungr at krefja eiðsins. ("The one which is called Mistletoe.

29 Snorri Sturluson, Edda Snorra Sturlusonar. Codex Wormianus AM 242, fol, ed. Finnur Jónsson (Copenhagen: Gyldendal, 1924), 3.

30 Sophus Bugge, Studier over de nordiske Gude- og heltesagns Oprindelse (Christiania: A. Cammermeyer, 1881-1898), 45. E.O.G. Turville-Petre, Myth and Religion of the North: the Religion of Ancient Scandinavia (London: Weidenfield \& Nicholson, 1964), 119. Heather O'Donoghue, "What has Baldr to do with Lamech? The Lethal Shot of a Blind Man in Old Norse Myth and Jewish Exegetical Traditions," Medium Ævum 72 (2005), 90-91. 
I thought it too young to demand an oath from.") ${ }^{31}$ The troublesome Loki, whom scholars have compared to Satan, wishes to kill Baldr, who has been compared to Christ. ${ }^{32} \mathrm{He}$ fashions a dart from mistletoe, and hands it to Baldr's blind brother to throw (a detail which has been compared to the story of Lamech). In the Sefer Toledot Yeshu ("Book of the Generations of Jesus"), a text with a number of variants which can be no older than the tenth century, there is a curious detail that all trees have agreed not to harm Jesus. ${ }^{33}$ Excepted was the cabbage, or sometimes the carob (the words are very similar in Hebrew, being

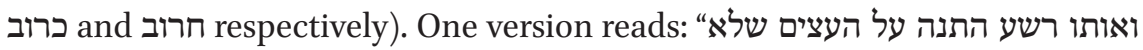
יקבלו אותו כשהין האותיות עמו מפני שידע שלא [י]"היו מניחין אותו וכל עץ שה שהיו תולין

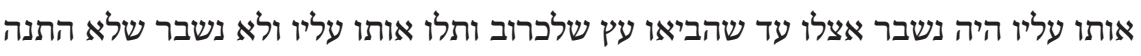
"על הכרוב "And that wicked one [Jesus] made it so that he had agreements with the trees because of his cunning that they would not receive him, and so all the trees they were to hang him on would break. Then they led him to the tree made of cabbage and hung him on that, but the cabbage had not agreed to break"). ${ }^{34}$ In some versions, the reason for the exception of the cabbage is said to be that it is not considered a tree, but a plant. Thus, it is either the cabbage stalk or the carob that must be used either to shape Jesus's cross, or from which to hang him. O'Donoghue sums up the analogue between mistletoe and the cabbage/carob thus:

It is striking that the carob might thus have been overlooked not only because of its manifest inherent unsuitability for the job, being physically — one might almost say botanically—unsuitable for such a role, but also because of a "category error": like the mistletoe, a parasitic plant with no independent stem, belonging midway between heaven and earth, it fell between the usual anthropological categories. Nevertheless, in both cases the overlooked item becomes the instrument of death without explanation of how it proves, after all, effective in its lethal role. ${ }^{35}$

31 Snorri Sturluson, Edda. Prologue and Gylfaginning, ed. Anthony Faulkes (London: Viking Society for Northern Research, 1988), 45 .

32 Arthur D. Mosher, "The Story of Baldr's Death: the Inadequacy of Myth in the Light of Christian Faith," Scandinavian Studies 55, no. 4 (Autumn 1983), 313-314.

33 Joseph Dan, "Toledot Yeshu," in Encyclopaedia Judaica, vol. 20, ed. Michael Berenbaum and Fred Skolnik (Detroit, MI: Macmillan Reference USA, 2007), 28-29.

34 Das Leben Jesu nach Jüdischen Quellen, ed. Samuel Krauss (Berlin: S. Calvary \& Co., 1902), 120.

35 O'Donoghue, "What has Baldr to do with Lamech?" 91. The article also points to a further analogue with the Aramaic Targum Sheni, ("Second Targum") where no tree will allow itself to be used as the gallows upon which Haman is hung. 
Of course, none of the scholars who have appreciated this parallel suggest a direct borrowing on behalf of Snorri, who obviously could never have read the Sefer Toledot Yeshu for himself. As O'Donoghue puts it "we can do little more than wonder, Casaubon-like, at these ancient correspondences, which also include... the overarching similarity between the circumstances of the deaths of both Baldr and Christ."36 Snorri almost certainly never spoke to a Jew, but it is quite plausible that he spoke to people who had. O'Donoghue goes on to note the connection between the Norwegian clerical elite and the Abbey of St. Victor. Norwegian students began attending St. Victor in the mid-twelfth century, a tradition that seems to have been established following the marriage of the abbot's sister to a Norwegian nobleman, and they continued to do so until the middle of the fourteenth century. ${ }^{37}$ The Victorines had a tremendous impact on ecclesiastical culture in Norway. A number of high-ranking Norwegian clergy were alumni, including Archbishop Eysteinn Erlendsson (d. 1181). During the thirteenth century, some forty Norwegians are recorded with the title magister/meistari, presumably a great deal of them having qualified in Paris. ${ }^{38}$ (The University of Paris, which emerged during the late twelfth century, had been founded by a consortium including the abbey of St. Victor, and the two institutions were largely contiguous throughout the Middle Ages). ${ }^{39}$ All five of the country's Augustinian monasteries were daughter establishments. There are no records of Icelanders attending, although it has been suggested that the abbey was where St. Porlákr studied while he was in Paris. ${ }^{40}$ The flow of traders, ecclesiastical personnel, and manuscripts between Iceland and Norway make it easy to imagine Norwegian Victorines being active in Iceland and perhaps Icelanders being inspired to study at St. Victor as a result. Even if only very few Icelanders visited the abbey in person, Victorine learning came to exert a great deal of influence on Old Norse literature. Adam of St. Victor (d. 1192), Godfrey of St. Victor (d. 1194), Hugh of St. Victor, and particularly in the case of Brandr Jónsson, ${ }^{41}$ Peter Comestor

36 O'Donoghue, "What has Baldr to do with Lamech?" 91.

37 Arne Odd Johnsen, "Studieresor. Norge," in KLNM, vol. 17 (1972), 332. All the following concerning Norwegian connections with St. Victor are from $33^{2-} 336$.

38 Ludvig Holm-Olsen and Kjell Heggelund, Norges Litteratur Historie. Fra Runene til Norske Selskab, vol. 1, ed. Edvard Beyer (Oslo: J.W. Cappelens Forlag, 1974), 328.

39 Gilbert Ouy, "Saint-Victor de Paris," in Histoire des bibliothèques françaises, vol. 1, ed. André Vernet (Paris: Promodès, 1989), 86.

40 Fredrik Paasche, Norges og Islands litteratur inntil utgangen av middelalderen, ed. Anne Holtsmark (Oslo: Aschehoug, 1957), 281.

41 Brandr Jónsson (d. 1264) was consecrated as Bishop of Hólar, the northern diocese of Iceland, in 1263. His Gyðinga saga (c. 1257) is an Old Norse history of the Jews, based 
(d. ca. 1179), were all known to Old Norse authors. ${ }^{42}$ When Snorri arrived at King Hákon's court in 1218, St. Victor had been the preferred destination of foreign study for Norwegians for almost a century. It would have been practically impossible for Snorri to have avoided its Norwegian alumni. It also seems unlikely that Norwegians studying abroad at such a prestigious institution would have turned their noses at the unique opportunity to study Hebrew and Jewish traditions. Indeed, even if Norwegian Victorines had not wished to avail themselves of St. Victor's considerable Hebrew resources, the environment of Jewish-Christian exchange at the abbey would have made it difficult to remain completely insulated from Jewish learning.

With this context in mind, the prospect that Jewish traditions might have exerted an influence on Snorra Edda becomes increasingly plausible. Let us turn now to the vignette with which we began: the confrontation where Pórr meets Hrungnir and Mǫkkurkálfi at Grjótúnagarðar.

Pá gerðu jǫtnar mann á Grjótúnagęrðum af leiri ok var hann níu rasta hár en priggja breiðr undir hǫnd, en ekki fengu peir hjarta svá mikit at honum sómði fyrr en peir tóku ór meri nokkvorri, ok varð honum pat eigi stǫðugt pá er Pórr kom. Hrungnir átti hjarta pat er frægt er, af hǫrðum steini ok tindótt með prim hornum svá sem síðan er gert var ristubragð pat er Hrungnis hjarta heitir. Af steini var ok hǫfuð hans. Skjqldr hans var ok stein, víðr ok bjokkr, ok hafði hann skjǫldinn fyrir sér er hann stóð á Grjótúnag̨rðum ok beið Pórs, en hein hafði hann fyrir vápn ok reiddi af oxl ok var ekki dælligr. Á aðra hlið honum stóð leirjǫtunnin, er nefndr er Mǫkkurkálfi, ok var hann allhræddr. Svá er sagt at hann meig er hann sá Pór. ${ }^{43}$

[Then, at Grjótúnagarðar, the giants made a man of clay, and he was nine leagues tall and three wide across the chest, but they could not find a heart that would fit him until they took one from a certain mare, and it

primarily on Maccabees and the Historia Scholastica. Brandr has also often been associated in part with Stjórn, a compilation of three annotated translations of the Pentateuch, although this association has largely been dismissed by Kirsten Wolf, "Brandr Jónsson and Stjórn," Scandinavian Studies 62 (1990), 163-188. Brandr's interest in Jewish history, seemingly quite untainted by anti-Judaism, is the matter for a separate study. Hans Bekker-Nielsen, "The Victorines and Their Influence on Old Norse Literature," in The Fifth Viking Congress. Tórshavn, July 1965, ed. Bjarni Niclasen (Tórshavn: Føroya Fróđskaparfelag, 1968), 32-36.

43 Snorri Sturluson, Edda. Skáldskaparmál 1, ed. Anthony Faulkes (London: Viking Society for Northern Research, 1998), 21. 
was not dependable for him when Pórr arrived. Hrungnir had a heart that is well known, of hard stone and pointed with three corners, made just as the runic character which is called "Hrungnir's heart." His head was also made of stone. His shield was also stone, wide and thick, and he held his shield in front of him as he stood at Grjótúnagarðar and summoned Pórr. He had a whetstone as a weapon which he swung about his shoulders, and it wasn't pretty. On the other cliff over from him stood the clay giant, whose name is Mǫkkurkálfi [Mud-leg], and he was terrified. It is said that he pissed himself when he saw Pórr.]

As previously stated, the concept of a leirjqtunn, "clay giant" instantly evokes one of the well-known figures of Jewish mysticism, namely the golem: an artificial anthropoid, sculpted from an earthy element such as dust or clay, and rendered animate through occult means. Although nowadays probably most famous from tales of the Prague based Rabbi Judah Loew ben Bezalel (d. 16og), the golem is in fact an extremely ancient figure, which was widely known and discussed across the Jewish Diaspora. It possibly originates as a Pan-Semitic tradition: it has been observed that Egyptian ushabti figurines from the second millennium B.C., being small clay anthropoids enchanted to obey the commands of their owner, constitute the earliest known analogue. ${ }^{44}$ Although widely assimilated into the realms of folklore and magic, the golem was originally intended to be a metaphor for the divine act of creation. The perfection of God's work would be highlighted by the imperfect nature of the rabbi's hulking, misshapen anthropoid. Indeed, the world golem [גלמ] literally means "a wrapped (and unformed mass, i.e. as the embryo):- substance yet being unperfect." ${ }^{45}$ The golem is primarily treated in the Talmud (200-500 A.D.) and the Kabbalah, chiefly in meditations on the Sefer Yeșirah (Book of Creation). However, the golem also appears in sources which were later incorporated into the Christian tradition. Psalm 139:15-16, for example: "My substance was not hid from thee, when I was made in secret, and curiously wrought in the lowest parts of the earth. Thine eyes did see my substance, yet being unperfect [Heb.: גלמי, golemî. Vulgate: informem ...me], and in thy book all my members were written, which in continuance were fashioned, when as yet there was none of them." In the apocryphal Acts of Peter and Paul, Simon Magus conjures a

See: Moshe Idel, Golem.Jewish Magical and Mystical Traditions on the Artificial Anthropoid (New York, NY: State University of New York Press, 1990), 3-4. Idel bases his discussion on: Bob Brier, Ancient Egyptian Magic (New York, NY: Quill, 1981), 170.

45 See Strong's H1516, in James Strong, Strong's Exhaustive Concordance of the Bible, updated ed. (Peabody, MA: Hendrickson, 2007), 1484. 
golem in order to demonstrate the extent of his powers. ${ }^{46}$ Interestingly, this moment is preserved in Old Norse. In Tveggja Póstola Saga Pétrs ok Páls, it is said that: Hann gerði orm or eiri, pann er skreið, oc hunda or steini, pa er go, oc likneski or malmi, pau er hlogu oc hrce(r)duz. ("He made a serpent out of brass, which crawled, and dogs out of stone, which barked, and statues out of metal, which laughed and moved." ${ }^{47}$ While Clemens saga, apparently drawing on the Pseudo-Clementine Recognitiones, features Simon Magus boasting that: "At boporpi mínu hlceia likneski pau es ger eru ór tré epa ór málmi ok hrorask pau ok mcela ef ek býp pat." ("At my command, statues that are made of wood or metal will laugh and move. They will speak, if I command it.' ") ${ }^{48}$

How far the idea of the golem penetrated Christian thought during the High Middle Ages has not been widely examined by scholars. It seems unlikely that, as the Early Church diverted from its once Jewish identity, an understanding of the references to the golem per se in the aforementioned episodes would have been retained. Nonetheless, these descriptions of magically animated homunculi would have brought the substance of the golem into Christianity, even if the name and the concomitant traditions were lost. Moreover, we must also consider the very probable eventuality that the golem was occasionally retransmitted into Christianity via contacts with Judaism. We know that the golem and the Sefer Yeșirah were being openly discussed by Jews and Christians in Germany and Italy by the late fifteenth century. ${ }^{49}$ However, it is not unthinkable that this process had begun much earlier. The thirteenth century saw a crescendo of interest in the golem amongst the Ashkenazim, the Northern European Jewish culture to which any Jews working with Victorines would have belonged. Joshua Trachtenburg cites an excerpt from De Universo by William of Auvergne (fl. 1228), as a Christian analogue to the golem, but the relationship may even stem from transmission rather than convergence. ${ }^{50}$ William of Auvergne had studied in Paris, and there become acquainted with Islamic and Jewish thinkers. He frequently quoted Solomon ibn Gabirol

46 Idel, Golem, 5-7.

47 "Tveggia Postola Saga Petrs ok Pals," in Postola Sögur, ed. by C.R. Unger (Christiania: B.M. Bentzen, 1874), 306.

48 Clemens Saga. The Life of St. Clement of Rome, ed. Helen Carron (London: Viking Society for Northern Research, 2005), 16.

49 Idel, Golem, $175^{-180 .}$

50 Joshua Trachtenberg, Jewish Magic and Superstition. A Study in Folk Religion (New York, NY: Behrman's Jewish Book House, 1939), 84-85. Trachtenberg actually mistakes a modern scholarly paraphrase for William's own words. See: Lynn Thorndike, A History of Magic and Experimental Science, vol. 2 (New York, NY: Columbia University Press, 1923), 353 . 
(d. ca. 1058), although he mistakenly believed him to be an Arabic Christian. William's work also often drew on Maimonides (d. 1204), although he never acknowledged him by name, probably owing to William's paradoxical antiJewish streak. ${ }^{51}$

Thus, when William writes the following, it is not impossible that he is attacking Jewish sources which he customarily refuses to name: "Sicut in libris experimentorum poteris invenire, similes etiam ludificationes mulierum eis, quas agunt incubi daemones, quidam malefici et attentaverunt, et scripserunt, posterisque reliquerunt, si tamen eis de talibus creditur." ("In books of experiments one can find mockeries of women resembling those which derive from the demons incubi. Some magicians also seduce them, and write about them, and then abandon them, if they are to be believed in this regard." ${ }^{52}$ The vague term libros experimentorum would certainly be an appropriate appellation for the Sefer Yeșirah and some other Kabbalistic texts, particularly as they would have been perceived by Christian outsiders. Moreover, as a student of Maimonides, William could well be expected to know the golem. Maimonides did discuss the golem, and in later folklore he was even rumoured to have created one himself. ${ }^{53}$ Naturally, the curious detail of sexual relations with the conjured being is not authentic to Judaism, but it does resonate with the Judaeophobic perception of Jewish magic as especially corporeal and sordid which we examined earlier. Indeed, even if this excerpt from William's writing is not demonstrative of a Christian discovering the golem through Hebraism, it seems hard to believe that it did not happen quite often during the twelfth and thirteenth centuries. Other Talmudic authorities, including Rashi, and the later Ashkenazi pietist Eleazar of Worms (d. 1238), treated the golem extensively.54 When a Victorine consulted a Jewish master on the meaning of Psalm 139, it seems hard to believe that the subject could have been avoided-particularly when Rashi's teachings were so predominant in the intellectual world of thirteenth century French Jews.

$5^{1} \quad$ Hans Liebeschutz, "William of Auvergne," in Encyclopedia Judaica, vol. 21 (Detroit, MI: MacMillan Reference, 2007), 64.

52 William of Auvergne, Guilielmi Alverni Opera Omnia Parisiis 1674. vol. 1, ed. Franciscus Hotot (Frankfurt: Minerva, 1963), 1072.

53 For Maimonides own words, see Hilkhot Yesode Ha-Torah 3:10. See also: Idel, Golem, 301305. For the later folklore, see Howard Schwartz, Tree of Souls: The Mythology of Judaism (Oxford: Oxford University Press, 2004), 284-285.

54 On Rashi and the Golem, see Idel, Golem, 30-31, 40, 75, 216-217, 275. On Eleazar of Worms, see Ibid., 20, 55-6o, 308-309, 313. 
So what might the relationship be between Moqkkurkálfi and the golem? Certainly, Mǫkkurkálfi is a magically animated anthropoid intended for an (un)life of service. Hrungnir, himself a giant made of stone, appears to be performing some kind of magical rite when he cuts the heart from a mare and uses it to animate Mokkurkálfi, who will then be expected to defend the giants against the ever irate Pórr. As in more didactically orientated tales of the golem, there is also the theme of the imperfection of creation when it is not undertaken by God. Mq̨kurkálfi is indeed "unformed"; although intended to be a fearsome weapon, he quivers with fear and loses control of his bladder when confronted with the sight of Pórr on the warpath. Moreover, the manner of his creation by Hrungnir brings to mind the kind of magic practiced in the Old Norse version of the miracle of Petronia cited earlier. Just like the warm urine trickling down Mǫkkurkálfi's thigh, or the naked lust in Dínus saga drambláta, Snorri makes the conception of the leirjptunn into something grossly physi$\mathrm{cal}$. Where the Jewish sorcerer from the Icelandic Homily Book used the kidney stone of an ox, Hrungnir and the giants use the heart of a mare.

Indeed, on closer inspection Hrungnir is surprisingly reminiscent of the archetypal Jewish magician in another way. Unlike Mokkurkálfi, who is attested only in Snorra Edda, he was certainly not imagined by Snorri. There are references to him in the Eddic poems Hárbarðsljóð (stz 14), Hymiskviða (stz 16), Lokasenna (stz 61, 63), Sigrdrifumál (stz 15), and Grottasongr (stz 9), which is the only other source which indicates that he was made of stone: Hardr var Hrungnir oc hans faðir ("Hard was Hrungnir and his father"). ${ }^{55}$ Hrungnir also appears in the skaldic verses Ragnarsdrápa and Haustlong. The implications of his stone heart have not gone unnoted by scholars. John Lindow has explored the binary opposition between the organic, normative "natural" Pórr and the stony, "unnatural" Hrungnir, while Bernard Martin suggests the heart is intended to invoke an air of "invulnerability" and "inhumanity." ${ }^{56}$ But there is one specific inference of "stony heartedness" in medieval culture which has gone uncommented upon. While Snorri did not invent Hrungnir, he may well have recognised and accentuated the anti-Jewish typological connotations of

55 See: Edda. Die Lieder des Codex Regius nebst verwandten Denkmälern, vol. 1, ed. Gustav Neckel and Hans Kuhn (Heidelberg: Carl Winter Universitätsverlag, 1983), 80, 90, 108, 109, $193,298$.

56 John Lindow, "Addressing Thor," Scandinavian Studies 6o, no. 2 (Spring 1988), 129. See also by the same author "Thor's Duel with Hrungnir" Álvíssmál 6 (1996), 3-20, especially 17. Bernard Martin, "Snorri's Myth about Hrungnir: Literary Perspectives," in Old Norse Studies in the New World, ed. Geraldine Barnes, Margaret Clunies Ross and Judy Quinn (Sydney, Nsw: Department of English, University of Sydney, 1994), 88, 90. 
his body. When he writes: Hrungnir átti hjarta pat er frcegt er, af horðum steini ("Hrungnir had a heart which is famous, made from hard stone"), he recalls the traditional appellation of the Jews as a "stony hearted people" - a polemical attack which Snorri would almost certainly have heard preached in church. ${ }^{57}$ As the Old Icelandic Homily Book itself states:

En póat allar hofopskepnor váttape hann gup vera. pa villdo öllvngis eige hiorto ớtrúra gybinga trúa hann gub vera. oc harpare steinom villdo pau eige kliúfasc til ipronar. oc vilia eige iáta peim er allar skepnor skilia gup vera. ${ }^{58}$

But even though all of the elements attested that He [Jesus] was God, then the hearts of the faithless Jews would by no means believe Him to be God, and harder than stones they would not be cracked for [their] repentance, and would not yield to Him, whom all of creation understands to be God.

Obviously, Hrungnir is not Jewish. But, to use a term coined by Jeffrey Jerome Cohen, Hrungnir is "Jew-ish."59 That is to say, he evokes the typological associations of the anti-Jewish symbolic vocabulary, without being intended as an explicit caricature of a Jew. It is appropriate that a "Jew-ish" magician should conjure a noticeably golem-ish anthropoid. Snorri would have needed only a passing or third-hand familiarity with the golem figure to make such an association. After all, the Jew-ishness of Hrungnir and the golem-ishness of Mq̨kkurkálfi are dependent on just two "facts" which would not have been accessible to Snorri through his affiliation with contemporary Christianity: (1) that Jews fashion clay anthropoids; (2) that such anthropoids are commonly imperfect. As seen, the Victorine connection to Norway would have been a convenient channel for the transmission of such knowledge. If Snorri did not necessarily know a great deal about the golem - he does not even have to have known that it was called "the golem" - it is also likely that his narrative sensibilities were not overpowered by its Jewish origins. For Snorri, the

57 Christopher Abram, Myths of the Pagan North: The Gods of the Norsemen (London: Continuum, 2011), 219-220.

$5^{8} \quad$ Homiliu-Bók, $5^{8}$.

59 Jeffrey Jerome Cohen, Medieval Identity Machines (Minneapolis, MN: University of Minnesota Press, 2003), 185. Cf., by the same author: "Was Margery Kempe Jewish?" In the Middle (21 April 2006), available online at http://www.inthemedievalmiddle .com/2006/04/was-margery-kempe-jewish.html. 
golem was probably little more than an intriguing image, idly heard at the court of King Hákon, and adapted to service no purpose other than adding a little further colour to the story of Pórr and Hrungnir. I would not propose that Snorri borrowed the image of the golem per se. Rather, I would speculate that he responded to it in a manner very similar to the response quoted in the epigraph to this essay. This was a case of inspiration, not appropriation.

A further possible footprint of the golem heading northwards, which would render Snorri's encounter less exceptional, can be found in Porleifs páttr jarlsskálds (in Flateyjarbók, of c. 1390, although the tale is most likely from around 1300). ${ }^{60}$ There, when the troublesome kraftaskáld Porleifr Rauðfeldarson composes a verse that magically molests the pagan Earl Hákon (d. 995), Hákon is eager for revenge. A devotee of the pagan deities Porgerðr Hoqrgabrúðr and Irpa, he turns to the occult in order to kill Porleifr:

En nú er par til at taka, er Hákon jarl er, at honum batnaði hins mesta meinlætis, en pat segja sumir menn, at hann yrði aldri samr maðr ok áðr, ok vildi jarl nú gjarna hefna Porleifi pessar smánar, ef hann gæti, heitir nú á fulltrúa sína, Porgerði Hǫrgabrúđi ok Irpu, systur hennar, at reka pann galdur út til Íslands, at Porleifi ynni at fullu, ok færir peim miklar fórnir ok gekk til fréttar. En er hann fékk pá frétt, er honum líkaði, lét hann taka einn rekabút ok gera ór trémann, ok með fjǫlkynngi ok atkvæðum jarls, en trǫllska ok fítonsanda peira systra, lét hann drepa einn mann ok taka ór hjartat ok láta í penna trémann, ok færðu síðan í fǫt ok gáfu nafn ok kǫlluðu Porgarð ok męgnuðu hann með svá miklum fjandans krapti, at hann gekk ok mælti við menn, kómu honum síðan í skiok sendu hann út til Î́slands pess erindis at drepa Porleif jarlsskáld. Gyrði Hákon hann atgeir beim, er [hann] hafði tekit ór hofi peirra systra ok Hǫrgi hafði átt. ${ }^{61}$

[And now Earl Hákon began to recover from the massive pain, and some people say that he was never quite the same man as he was before, and the Earl now wanted to avenge Porleifr for this embarassment if he could, calling on his patron deities, Porgerðr Hǫrgabrúðr and her sister, Irpa, to project their magic out to towards Iceland so that Porleifr would be utterly vanquished, and he offered them great sacrifices and requested news. And when he received news which was to his liking, he had a piece of driftwood taken and made from it a wooden man, and by the magic and incantation of the earl and the magic and the ecstatic witchcraft of

6o Jónas Kristjánsson, Introduction to Porleifs páttr jarlsskálds in Eyfirðinga Sögur, ed. Jónas Kristjánsson (Reykjavík: Hið Íslenzka Fornritafélag, 1956), xciv. 
those sisters he had a man killed, took from him his heart, had it put into the wooden man and then had it set on its feet and gave it a name. It was called Porgarðr, and he bewitched it so much by the power of the devil that it walked around and spoke to people. Then he put him on a ship and sent him out to Iceland on a mission to kill Porleifr "The Earl's Poet." Hákon armed him with a halberd which he had taken out of the shrine of the sisters and which once had been owned by Horgi.]

The similarity between Porgarðr and the golem has been briefly alluded to several times in secondary criticism, although no commentator has explored the similarities in full. ${ }^{62}$ Firstly, reminiscent of the mare's heart given to Moqkkurkálfi, there is the inserted heart. The concept of a murdered victim being part of the ritual was present in early configurations of the golem legend. ${ }^{63}$ Secondly, although golems were usually thought to be made of dust or clay, wooden golems were not unknown. We have already seem this in an Old Norse context from Pétrs saga Postola, where Simon Magus's walking, talking golem has remarkable affinities with the trémaðr. Indeed, Solomon ibn Gabirol, of whom William of Auvergne was so fond, was said to have assembled a golem out of wood. ${ }^{64}$ We should note too, that the tré ("wood") of which this trémaðr consisted was apparently construed as a particularly earthy element. When Porgarðr's work is done, he does not fall down as a pile of sticks, but, in a manner which to me seems more reminsicent of the golem returning to dust: hann steyptist íjgrðina niðr, svá at i iljarnarvar at sjá ("he plunged down into the earth so that only the footprints could be seen.") ${ }^{65}$ Thirdly, like the animation of a golem, the creation of Porgarðr seems to have not only a magical but a religious significance. It is figured as a kind of worship towards Porgerðr Hǫrgabrúðr and Irpa; a reaffirmation of deference to a deity.

62 See Kate Heslop, "Porleifr jarlsskald Rauðfeldarson' [biography]," in Skaldic Poetry of the Scandinavian Middle Ages 1: From Mythical Times to c. 1035, ed. Diana Whaley (Turnhout: Brepols, 2012), 367; Elton O.S. Medeiros, "Hávamál: tradução comentada do Nórdico Antigo para o Português," Mirabilia 17 (2013), 567; Leszek Pawel Słupecki, "The Scandinavian God Thor and His Ancient Roots," Quaestiones Medii Aevi Novae 9 (2004), 238. Richard North, Introduction to The Haustlong of Pjódolfr of Hvínir (Enfield: Hisarlik Press, 1997), lxii-lxiii.

63 Idel, Golem, 7-8.

64 Schwartz, Tree of Souls, 280-281.

65 porleifs páttrjarlsskálds, 226. 


\section{Conclusion}

By way of conclusion, we can recapitulate how much knowledge of Jewish magical and exegetical practices would have been current in Scandinavia by the end of the thirteenth and beginning of the fourteenth century. Much as in other regions of Europe, amongst lay people there seems to have existed a popular perception that Jews were particularly gifted with supernatural abilities. Common anti-Jewish tropes regarding corporeality and hostile intent were intrinsic to this preconception. Doubtless encouraged by the stereotype of the Jewish sorcerer, garbled Hebrew words were commonly used in runic inscriptions intended for magical purposes. Through the inter-religious learning of the Victorines, some tangible transmissions from the medieval Jewish world became available to Scandinavians. As seen in the case of $\mathrm{N}_{348}$, some Scandinavians probably attempted to grasp the rudiments of Hebrew. Also owing to the Victorine connection with Norway, Snorri Sturluson may well have enjoyed second- or third-hand familiarity with the Sefer Toledot Yeshu. Although at an unusually northern latitude for such cultural osmosis to have taken place, both Snorri and the anonymous author of Porleifs sagajarlsskálds appear to have been influenced by the potent image of the golem: neither Porgarðr nor Mǫkkurkálfi are themselves the golem proper, but they may yet be the shadows cast by his lumbering frame.

\section{Acknowledgements}

I am indebted to Marteinn Helgi Sigurðsson for informing me about Porgarðr in Porleifs saga jarlsskálds, as well as providing many other helpful suggestions along the way. Christian Etheridge also first encouraged me to consider the Victorine influence on medieval Scandinavian learning. I am grateful to Andrew Walton for discussing $\mathrm{N}_{348}$ with me, and to Jonas Wellendorf for his many insightful suggestions. The original impetus for this study came from discussions with Richard North and Israel Sandman. Any errors are my own. 